\title{
Analysis of Graduate Relevance to Program Learning Outcome Mechanical Engineering in State University of Surabaya
}

\author{
Heru Arizal1 $^{*}$, Tri Hartutuk Ningsih ${ }^{2}$, Ali Hasbi Ramadani ${ }^{3}$, Ika Nurjanna ${ }^{4}$, Husni Mubarok ${ }^{5}$ \\ 1,2,3,4Universitas Negeri Surabaya, Surabaya, Indonesia \\ ${ }^{5}$ National Taiwan University of Science and Technology, Taipei, Taiwan
}

\begin{tabular}{|c|c|}
\hline (A) check for updates open 0 access (c) (i) (2) & DOI : https://doi.org/10.46245/ijorer.v3i1.180 \\
\hline Sections Info & ABSTRACT \\
\hline Article history & \multirow{10}{*}{$\begin{array}{l}\text { The college is one of the create of professional and qualified Human resource.. } \\
\text { Universities must develop following the development needs of the business } \\
\text { world and the industrial world. The purpose of this study was to analyze the } \\
\text { relevance of Mechanical Engineering graduates to the Program Learning } \\
\text { Outcome and as material for curriculum evaluation. The subjects of this } \\
\text { research were } 120 \text { graduates in } 2019 \text { and } 2020 \text {. The technique of collecting data } \\
\text { was using a questionnaire through the State University of Surabaya Tracer } \\
\text { Study web. The data is then analyzed using quantitative descriptive. As many } \\
\text { as } 55.83 \% \text { of alumni are already working, } 32.5 \% \text { are not working, } 10 \% \text { are } \\
\text { entrepreneurs, and the rest are continuing their education. The waiting time } \\
\text { for graduates to get a first-time job takes an average of } 4.49 \text { months. The total } \\
\text { relationship between the field of work and the field of education has a very } \\
\text { tight, tight and pretty tight relationship of } 77.5 \% \text {. The profile of a mechanical } \\
\text { engineering graduate is to become a mechanical engineer. The number of } \\
\text { graduates who match the graduate profile is } 61.2 \% \text {. The competence of } \\
\text { graduates is still below the competencies needed by the business and } \\
\text { industrial. From the data above, we can conclude that graduates from the } \\
\text { mechanical engineering study program are relevant to the established } \\
\text { Program Learning Outcome. }\end{array}$} \\
\hline ecember 10, 2021 & \\
\hline Final Revised: January 3, 2022 & \\
\hline Accepted: January 11, 2022 & \\
\hline 1,2022 & \\
\hline & \\
\hline m Learning Outcome & \\
\hline & \\
\hline & \\
\hline & \\
\hline & \\
\hline
\end{tabular}

\section{INTRODUCTION}

Alumni need an average of 1 month in getting a first-time job after graduating from education. Their first job is getting the most in three ways, namely through relationships, social media and college career centers. The majority of graduates work in accordance with the field of study, but they need to improve their skills in foreign languages, especially when they work abroad, as well as the ability in the field of computers to support their work (Razak et al., 2019). Department of Economics and Development Studies alumni take 4 years to complete the study period as many as $71 \%$ of alumni, this shows students in the IESP major the majority of their study period is on time. The waiting time to get a first-time job is less than 6 months as much as $76 \%$ of alumni. Department of Economics and Development Studies alumni mostly work in national private companies, especially at financial institutions as much as $66 \%$, this shows that Department of Economics and Development Studies alumni work in fields that are in accordance with the area of expertise pursued during the study period. Alumni users $82 \%$ stated that the use of IT by alumni has a good value category (Daeng et al., 2021).

Alumni' first-time jobs get less than 6 months after graduation. Salary and benefits are the deciding factors in the establishment of a career from a first-time job. Alumni assess that the curriculum provided by the college is relevant and greatly contributes in 
supporting their work. Communication skills and self-confidence are considered the most supportive in the workplace (Cornillez et al., 2021). The majority of respondents had permanent or regular employment and worked locally within the region, according to the findings. Graduates were hired within 1 to 6 months of graduation, and their initial and current work levels were professional, technical, or supervisory. Salaries and benefits were the most important reasons in graduates' changing initial jobs. Furthermore, graduates viewed the breadth of the curriculum as useful, with general education and teaching practicum learning areas being the most relevant and contributing the most to their work. The most useful job competencies and values are communication, human interactions, and self-assurance. The academic training of students has tremendously benefited their employment prospects (Cormillez et al., 2021).

The studies revealed that the graduates had 90 percent of the abilities expected of them, among other things. The Mechanical Engineering Craft Practice Trade graduates, on the other hand, lacked ten percent of the skills. Graduates of the The Mechanical Engineering Craft Practice Trade trade should, among other things, have various machine safety and machine operational abilities that aren't required for employment or self-reliance (Mele et al., 2020). Significantly, the study found that graduates very easily acquired first-time work in various industries in the fields of consulting, maintenance and repair, and electric utilities. Spreading their job positions as supervisors, designers even become academics. The curriculum that has been established by the college has a positive and significant impact on getting a job. Competencies that support their work are lifelong learning, critical thinking, problem solving, and communication skills (Pontilla, 2018)

Datong's research states that graduates are very easy to get a job, where the percentage rate of graduates who have worked is $95.54 \%$. The majority of graduates work as associate professionals in Philippine manufacturing companies. Their work is closely related to their education. Alumni endure at least three years after obtaining a first-time job. Communication is the most important competency provided in college and has proven to be very effective in supporting their work (Dotong et al., 2016). Human relations and communication skills are the most closely related abilities obtained by the University's maritime graduates. The curriculum and acquired necessary skills and technical knowledge are among the many school-related aspects that contribute to current employment and are significant to the job placement of marine graduates. They deemed navigation and shipboard training to be extremely important for Marine Transportation graduates, whereas professional courses in electro and automation are extremely important for Marine Engineering graduates (Gonzales, 2019).

The bulk of respondents (71.4 percent) are teachers/lecturers, 12.7 percent work in other industries, and 15.9 percent have never worked. Furthermore, according to statistics acquired, as many as 49.2 percent of graduates find work during a period of 0 to 11 months, 36.5 percent find work between 11 and 23 months, and 14.3 percent find work for more than two years. The majority of responders suggested rewriting the curriculum so that the study program may continue to evolve and respond to current difficulties (Soedjamiko, 2018). Graduates are an asset for agencies in analyzing the curriculum that has been carried out. Therefore, universities must conduct tracer study activities periodically. In this research we want to analyze the relevance of graduates to 
Analysis of Graduate Relevance to Program Learning Outcome Mechanical Engineering in State University of Surabaya

the Learning Outcome Program has been set at bacelor Mechanical Engineering, Surabaya State University.

\section{RESEARCH METHOD \\ General Background}

This research is a quantitative study that aims to find out the relevance of Program Learning Ooutcome from the point of view of participants from both alumni and stakeholders. Quantitative research is descriptive of analytics. Data is obtained from questionnaires distributed to alumni and stakeholders with the help of applications such as google form. The results of the analysis in the form of exposure to the relevance of Program Learning Outcome in the form of narratives that aim to describe events and analyze the relevance of graduates to Program Learning Outcome Bachelor Mechanical Engineering Surabaya State University.

\section{Participants}

The population in this study is a bachelor of mechanical engineering alumni who graduated in 2019 and 2020 as many as 120 alumni. In this study the sample used is a saturated sample, which is where the entire population is used as a research sample.

\section{Instrument and Procedures}

The instruments in this study used online questionnaires through google form. Alumni open the website using usernames and passwords that have been sent via their personal email.

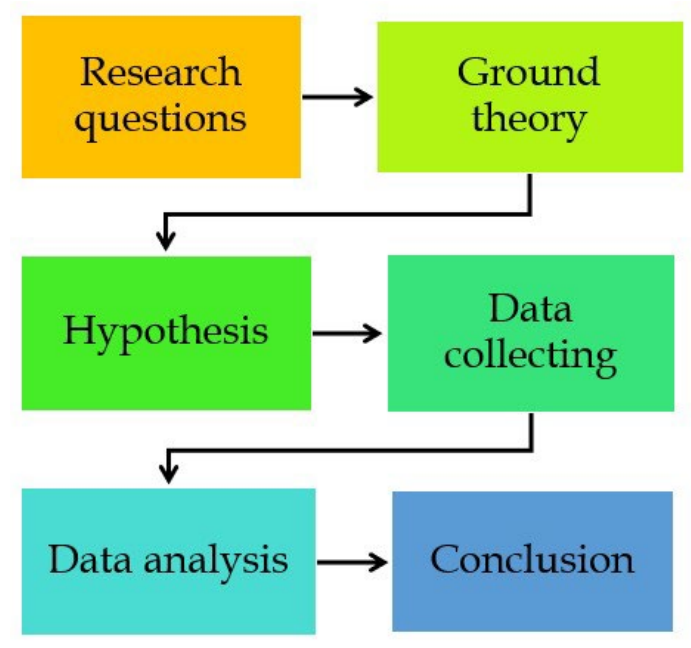

Figure 1. Research procedure.

\section{Data Analysis}

Data that has been collected, collected and will be analyzed. The data analysis uses the technique of descriptive analysis of the kuantitats. Where the data will be presented in the form of a graph, the table is then desked.

\section{RESULTS AND DISCUSSION}

\section{Results}

The condition of alumni after graduation is an indicator of the success of the learning process during education. The condition of alumni after graduating the most percentage, namely the condition has worked at $55.83 \%$. While the percentage of alumni conditions is at least being continued education to a higher level. Alumni who 
have not worked the percentage is $32.5 \%$, of which $27.5 \%$ of alumni are looking for work and $5 \%$ are not yet possible to work (married, sick). There are alumni who develop independent businesses/entrepreneurship as many as 12 alumni or as many as 10 of alumni who have worked.

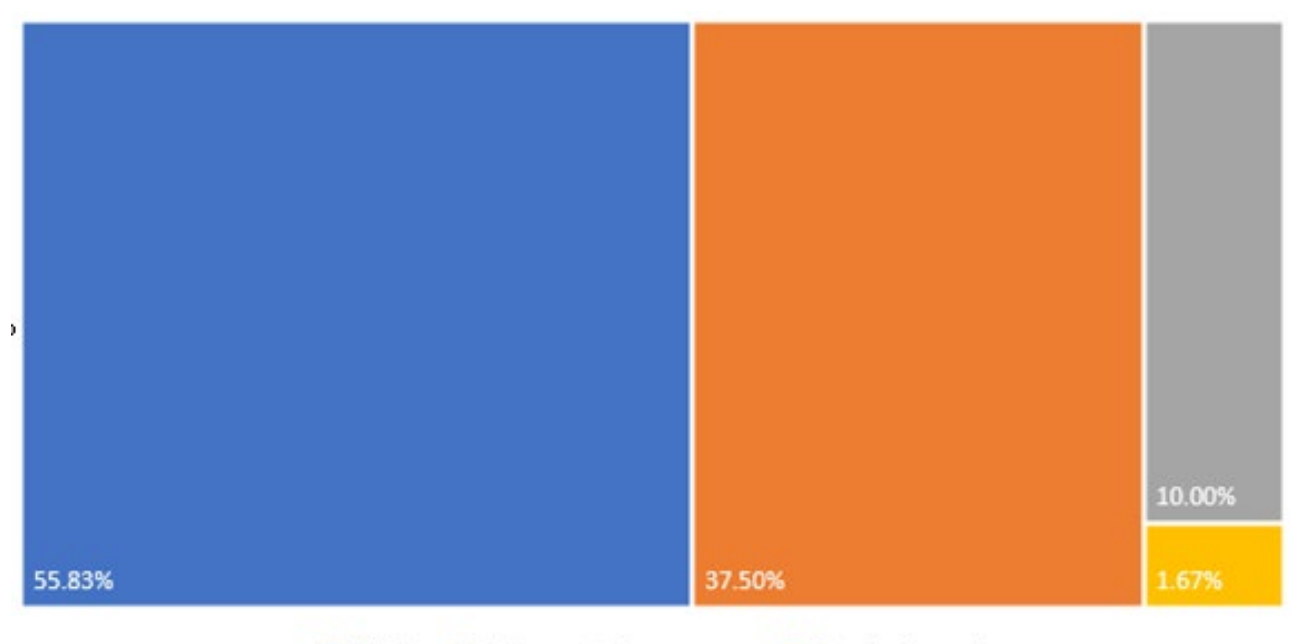

- Worker Jobless Entrepreneur $=$ Continuing study

Figure 2. Alumni condition after graduation.

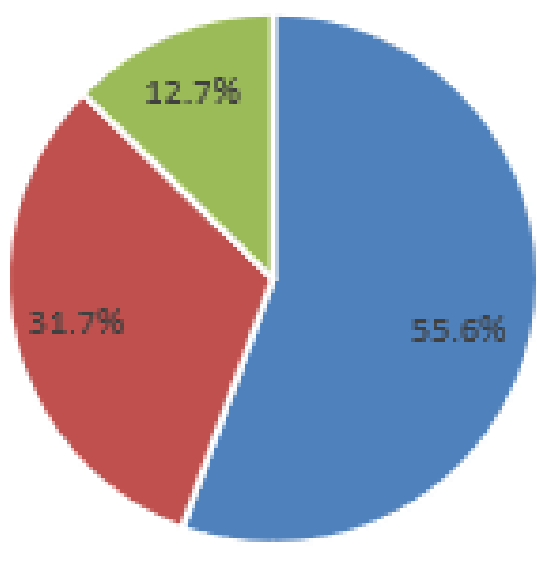

$=0-3$ month $\quad=3-6$ month $=6-12$ month

Figure 3. First time job waiting time.

As many as 67 alumni who have worked, $55.6 \%$ said they got a first job in less than 3 months or as big as that. There are 8 alumni waiting for the first job takes between 6-12 months. The waiting time of 3-6 months experienced by alumni to get a first-time job is $31.7 \%$. The average alumni to get a first-time job takes 4.49 months. Graduates in 2019 average wait times to get a first-time job faster than graduates in 2020, where the waiting time in 2019 takes 3.78 months. Alumni 2020 waiting time is longer than 2019 graduates because when they graduated conditions in Indonesia are experiencing the Covid-19 pandemic. In 2020 - 2021 the Indonesian economy is in turmoil, so many companies are laying off their employees and rarely companies that open job openings. This is what is experienced by alumni of Bachelor Mechanical Engineering. 
Analysis of Graduate Relevance to Program Learning Outcome Mechanical Engineering in State University of Surabaya

\begin{tabular}{clc}
\multicolumn{3}{c}{ Table 1. Suitability of the field of work with education. } \\
\hline No & Suitability of The Field of Work with Education & Percentage \\
\hline 1 & Higher level & $9,9 \%$ \\
2 & Same level & $78,9 \%$ \\
3 & Lower level & $11,3 \%$ \\
4 & No need for higher education & $0 \%$ \\
\hline
\end{tabular}

The table above shows the position of the relationship between their field of work and the level of education. The majority of alumni stated their current work in accordance with their level of education, namely Bachelor Mechanical Engineering, The alumni were also able to compete with higher education than them this was shown as much as $9.9 \%$ of them did jobs that should require higher education. There are currently alumni who work with competitors below their education level of $11.3 \%$.

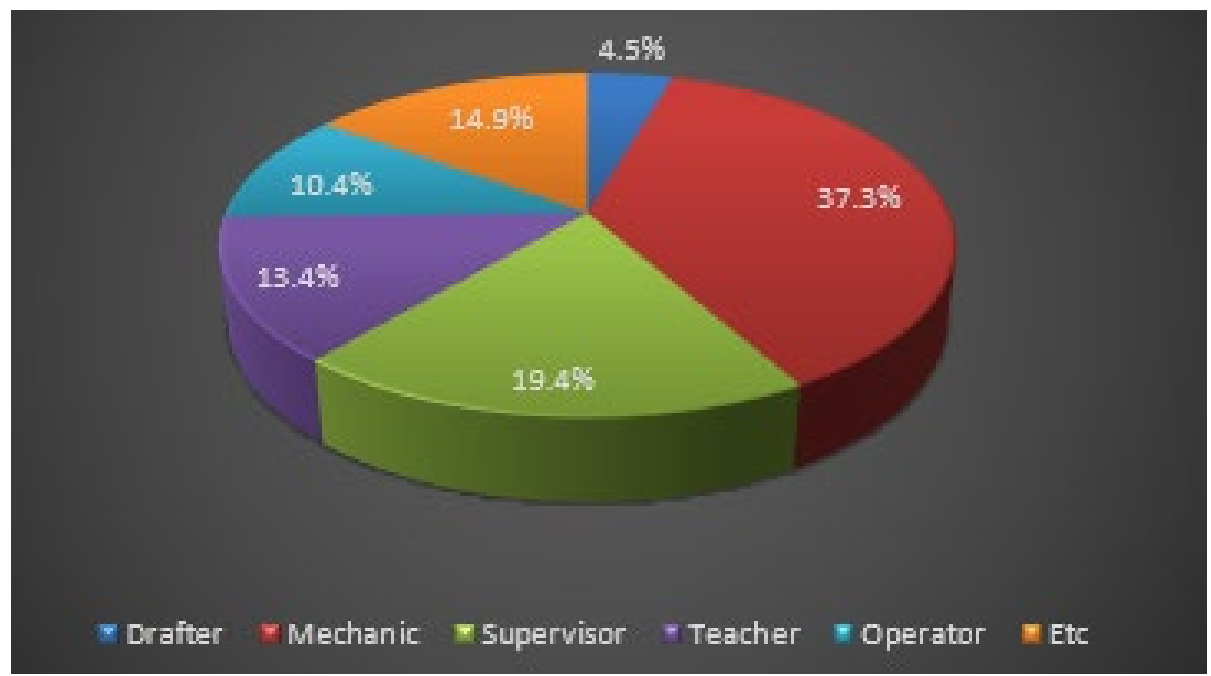

Figure 4. Alumni job type.

The graduate profile of bachelor mechanical engineering is an engineering engineer in mechanical engineering where he can become a mechanic, dafter, supervisor. So alumni who fit the profile of graduates of bachelor mechanical engineering by $61.2 \%$. The average working alumni does not fit the profile of graduates because they see existing job opportunities, so they do not attach importance to the field of education. They are thinking of working as quickly as possible, because the current conditions are very difficult to get a job. For them also the first job is used as a stepping stone to an even better job. Alumni also want to become teachers and production operators, namely by $13.4 \%$ and $10.4 \%$. There are $14.9 \%$ of alumni working in other types of jobs, such as being a costumer service, administration, quality control.

Table 2. Employment relationship with the scientific field.

\begin{tabular}{clc}
\hline No & Relationship of Field of Work with Scientific Field & Percentage \\
\hline 1 & Very tight & $28.2 \%$ \\
2 & Tight & $26.8 \%$ \\
3 & Pretty tight & $22.5 \%$ \\
4 & Less tightly & $15.5 \%$ \\
5 & Not related at all & $7.0 \%$ \\
\hline
\end{tabular}


Relevance of the scientific field to the field of work is an indicator of graduate willingness towards Program Learinng Outcome Bachelor Mechanical Engineering. The table shows the total insecurity of employment relationships with scientific fields is $77.5 \%$. While $15.5 \%$ said their work was less closely related to the field of education they took during college. There are even alumni who have nothing to do with their education, which is $7 \%$.

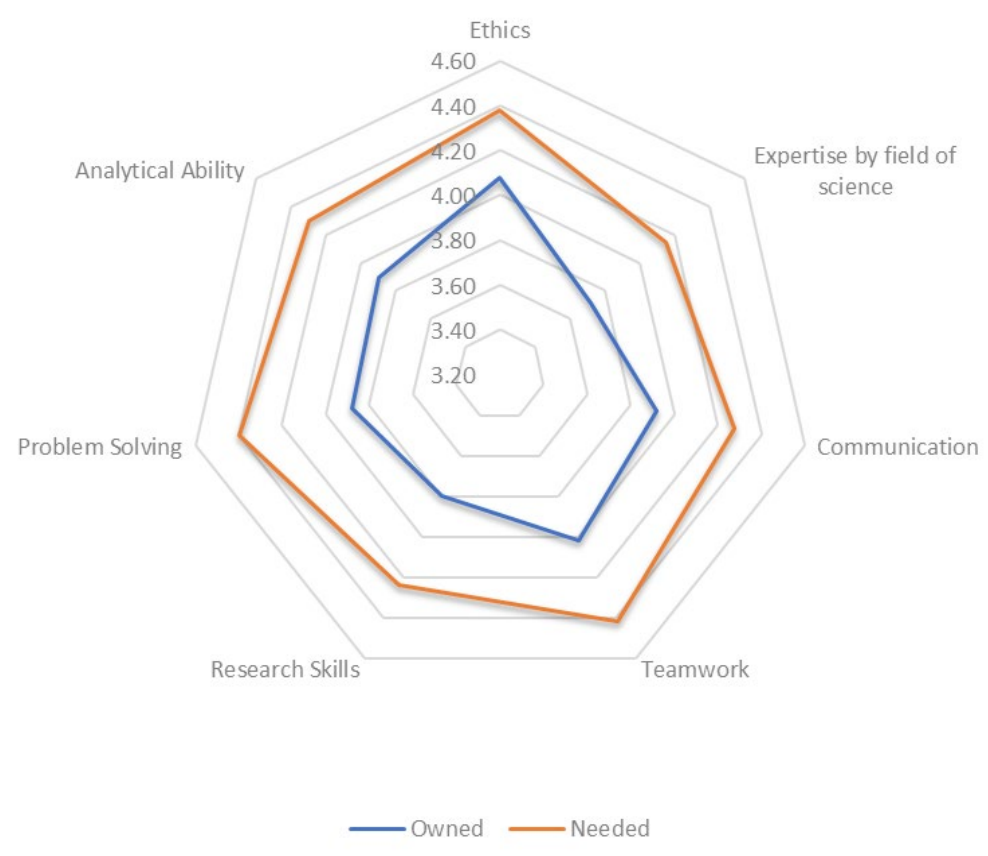

Figure 5. Comparison of competency level of needs with competencies possessed.

The picture above we can see that the greatest competency need is problem solving which is 4.40 . While the least competence needs is expertise in the field of science. The competence of the highest alumni is in the competence of teamwork with a score of 4.02. The largest gap between the required competencies and the competencies possessed is in problem solving of 0.52 .

\section{Discussion}

The condition of alumni who work in study tracer activities is $55.83 \%$ and alumni who have not worked $32.5 \%$. The cause is due to the current condition in the Covid-19 pandemic. Alumni who have not worked the majority of them expressed difficulty in finding a job, because companies rarely open jobs, and companies are massively laying off. There are entrepreneurship alumni of $10 \%$ and $1.67 \%$ of alumni continuing further study. From the data it is known that graduates from mechanical engineering degrees have the ability to work and continue their education in accordance with their field of expertise. As for the 36 alumni who continue to try to find a job because they believe in the competencies they get during their education. There are 6 alumni who do not allow work at this time because they are married so they are not allowed by their husbands to work and there are those who are sick.

The average working alumni takes a minimum of 4.49 months. Graduates in 2019 average wait times to get a first-time job faster than graduates in 2020, where the waiting time in 2019 takes 3.78 months. Alumni 2020 waiting time is longer than 2019 
graduates because when they graduated conditions in Indonesia are experiencing the Covid-19 pandemic. In 2020 - 2021 the Indonesian economy is in turmoil, so many companies are laying off their employees and rarely companies that open job openings. This is what is experienced by alumni of Bachelor Mechanical Engineering. The waiting time for graduates majoring in education and sports coaching of Semarang State University requires $0-11$ months as much as $49.2 \%$ to get a first-time job (Soedjatmiko, 2018). Bachelor Mechanical Engineering waiting time is better because their waiting time is less than 3 is already $55.6 \%$ when compared to graduates from sports education and coaching majors. The position of the job is considered to be in accordance with the level of education, namely undergraduate. Although the position of alumni does not match the profile of graduates but the field of work they are involved in requires a Bachelor's equivalent education. About $9.9 \%$ of alumni dare to take jobs that require a higher level of education than their education. This is because they already have experience, so they have a plus in the company to occupy their positions.

The graduate profile of bachelor mechanical engineering is an engineer in mechanical engineering where he can become a mechanic, dafter, supervisor. So alumni who fit the profile of graduates of bachelor mechanical engineering by $61.2 \%$. The average working alumni does not fit the profile of graduates because they see existing job opportunities, so they do not attach importance to the field of education. They are thinking of working as quickly as possible, because the current conditions are very difficult to get a job. For them also the first job is used as a stepping stone to an even better job. Graduates from Mechanical Engineering Craft Practice Trade Of Government Technical Colleges In Adamawa And Borno States of Nigeria obtained data that the knowledge obtained during school supports $90 \%$ of their work (Mele, 2020). Therefore, graduates of mechanical engineering only reached $61.2 \%$ who worked in accordance with their fields, it is necessary to increase competence and knowledge of students before they graduate, so that when they graduate it will be easy to get a job in accordance with their scientific field.

Problem solving is the most needed competency in the company, also the largest gap compared to the competence possessed. Problem solving in the company is more complex than giving problem solving while studying. Ethics has the smallest competency gap between the required competencies and the competencies they have. Ethics is also the most highly owned complement of graduates in comparison. Research skills are the weakest alumni competence when compared to the competencies in Program Learning Outcome Bachelor Mechanical Engineering. This weakness is due to research only done in the final semester, namely when performing the final task / thesis. According to Cagasan (2017) the skills needed in the field of work then the scientific ability of the field most influential on the field of work.

Program Learning Outcome Bachelor Mechanical Engineering is still relevant to what is needed by the business world and the industrial world. This is shown the level of conformity and synergy in the field of education with the field of work, but bachelor Mechanical Engineering must improve the quality of education again because there is still a large gap between the competencies needed and the competencies possessed by alumni. Similarly, delivered by Cagasan (2017) as many as $92 \%$ of respondents stated that Visayas University graduates are very relevant to their field of work to their scientific fields. 
Analysis of Graduate Relevance to Program Learning Outcome Mechanical Engineering in State University of Surabaya

\section{CONCLUSION}

The Program Learning Outcome that has been formulated by Bachelor Mechanical Engineering is still relevant to the needs of the business and the industrial world. This relevance can be seen in the type of graduate employment where there is $61.2 \%$ according to the profile of graduates. And we can only see in terms of the relationship of the field of work with their education where $77.5 \%$ of the scientific field is totally close to the field of work. There is still a competency gap owned by alumni with competencies needed by the company, especially in problem solving competencies. Meanwhile, there are still alumni who have not worked, therefore the department of mechanical engineering helps build cooperation with agencies or companies so that the department can channel graduates to companies that have established cooperation. The research continues to be developed the data comes also from a combination of alumni and users, in order to get more accurate data. The results of this study tracer can be used as a consideration for improving the quality of education, ranging from curriculum, implementation, development, facilities and infrastructure.

\section{REFERENCES}

Abana, A. S., Ramos, A. B., Gumarang, B. K., \& Tarun, J. Z. (2021). The graduates tracer study: Bachelor of elementary education program. International Journal of Multidisciplinary: Applied Business and Education Research, 2(10), 918-927. http://doi.org/10.11594/ijmaber.02.10.09

Andari, S., Setiawan, A. C., Windasari., \& Rifqi, A. (2021). Educational management graduates: A tracer study from universitas negeri Surabaya, Indonesia. IJORER: International Journal of Recent Educational Research, 2(6), 671-681. https://doi.org/10.46245/ijorer.v2i6.169

Bueno, D. C. (2017). Ascertaining the curriculum relevance of the graduate school through tracer study in a Philippine private higher education institution. JPAIR Multidisciplinary Research Journal, 28(1), 72-88. https://doi.org/10.7719/jpair.v28i1.502

Buenviaje, M. G., del Mundo, G. V., Añonuevo, F., \& Martinez, M. (2015). Employability of business and computer management graduates of one higher education institution in the Philippines. Asia Pacific Journal of Multidisciplinary Research, 3(5), 1-9.

Cagasan, E., Dargantes, T. M., Florentino, N. N., Lasquites, H. S. (2017). Tracer study of the graduate degree programs of the Visayas state university. Science and Humanities Journal, 11(1), 16-39. http:/ / doi.org/10.47773/shj.1998.110.2

Celis, M. C., Festijo, B., \& Cueto, E.A. (2013). Graduate's employability: A tracer study for bachelor of science in hotel and restaurant management. Asian Academic Research Journal of Multidisciplinary, 1(11), 225-238.

Cornillez, E. E. C., Caminoc, S. R. T., Basas, B. R., Militante, B. T., \& Paler, R. R. (2021). Tracer study of teacher education graduates of the eastern Visayas state university-Tanauan campus, Philippines. Europen Journal of Education and Pedagogy, 2(3), 1-7. http://doi.org/10.24018/ejedu.2021.2.3.143

Cuandra, L. J., Aure, M. R. K. L., \& Gonzaga, G. L. (2019). The use of tracer study in improving undergraduate programs in the university. APHERJ, 6(1), 13-25.

Finch, D. J., Hamilton, L. K., Baldwin, R., \& Zehner, M. (2013). An exploratory study of factors affecting undergraduate employability. Education Training, 55(7), 681-704, https://doi.org/10.1108/ET-07-2012-0077

Daeng, A., Rois, I., \& Paranata, A. (2021). Analisis penelusuran alumni (tracer study) pada pengguna alulmni program studi IESP fakultas ekonomi dan bisnis universitas Mataram lulusan tahun 2014-2019. Jurnal Ekonobis, 7(1), 4065. https://doi.org/10.29303/ekonobis.v7i1.68 
Analysis of Graduate Relevance to Program Learning Outcome Mechanical Engineering in State University of Surabaya

De Castro, E. L., Prenda, M. T. B., \& Dotong, C. I. (2017). Employability of computer engineering graduates during academic year 2015-2016 and their lifelong learning options. Asia Pacific Journal of Academic Research in Social Sciences, 2(1), 58-66.

Dotong, C. I., Chavez, N. H., Camello, N.C., De Castro, E. L., Prenda, M. T. B., Laguador, J. M. (2016). Tracer study of engineering graduates of one higher education institution in the Philippiness for academic year 2009-2012. European Journal of Engineeing and Technology, $4(4), 26-39$.

Fenta, H. M., Asnakew, Z. S., Debele, P. K., Nigatu, S. T., \& Muhaba, A. M. (2019). Analysis of supply side factors influencing employability of new graduates: A tracer study of Bahir Dar university graduates. Journal of Teaching and Learning for Graduate Employability, 10(2), 67-85. https:// doi.org/10.21153/jtlge2019vol10no2art801

Gines, A. C. (2014). Tracer study of PNU graduates. American International Journal of Contemporary Research, 4(3), 81-98.

Gonzales, A. A. (2019). Tracer study of maritime graduates of one private academic institution in the Philippines from 2012-2017. Asia Pacific journal of Maritime Education, 5(1), 22-33.

Laguador, J. M., \& Dotong, C. I. (2013). Tracer study of bs computer engineering graduates of lyceum of the Philippines university. International Journal of Management, IT and Engineering, 3(8), 387-401.

Loquias, R. T. (2015). Employability of the bachelor of science in electronics engineering graduates of camarines sur polytechnic colleges. Asia Pacific Journal of Multidisciplinary Research, 3(4), 33-40.

Mele, E. F., Abana J., \& Haruna AI. (2020). Tracer study on skills possessed by graduates of mechanical engineering craft practice trade of government technical colleges in adamawa and borno states of Nigeria. International Journal of Engineering Tecchnologies and Management Research, 7(12), 17-24. https://doi.org/10.29121/ijetmr.v7.i12.2020.828

Menez, N. L. (2014). Tracer study of the masters in business administration (MBA) graduates from 2008-2012. Asia Pacific Journal of Education, Arts and Sciences 1(1), 14-18.

Mina, J. C., Reyes, E. J. G., \& Salas, R. F. (2020). A tracer study of bachelor of science in information technology (BSIT) graduates of nueva ecija university of science and technology (NEUST), san isidro campus. International Journal of English Literature and Social Sciences, 5(4), 1337-1344. https://doi.org/10.22161/ijels.54.77

Pannogan, O. C., \& Ocampo, D. P. (2016). Tracer study of bachelor of arts graduates major in English. International Journal of Advanced Research in Management and Social Sciences, 5(1), 281-297

Pontillas, V. V. (2018). Tracer study on bachelor of science in electrical engineering graduates of a polytechnic college in the Philippines from 2007 to 2010. Asia Pacific journal of Maritime Education, 6(2), 36-46.

Razak, F., \& Kamaruddin, R. (2019). Tracer study STKIP alumni andi matappa. Global Science Education Journal, 1(2), 194-203.

Sharif, A. M., Kiong, T. T., Zakaria, Asimah, N., \& Salih, M. (2017). Graduates of living skills program of a Malaysian public university: A tracer study. Journal of Asian Vocational Education and Training, 10(1), 53-64.

Siraye, Z., Abebe, T., Melese, M., \& Wale, T. (2018). A tracer study on employability of business and economics graduates at Bahir Dar university. International Journal of Higher Education and Sustainability, 2(1), 45-63.

Soedjatmiko. (2018). Tracer study relevansi kompetensi lulusan program sudi pendidikan kepelatihan olahraga dengan kebutuhan lapangan kerja. Journal of sport coaching and physical education, 3(1), 1-7. https://doi.org/10.15294/jscpe.v3i1.31880

Sugiyono. (2015). Metode penelitian pendekatan kuantitatif, kualitatif dan RED. Alfabeta.

Sugiyono. (2016). Metode penelitian kuantitatif, kualitatif dan RED. PT Alfabet.

Rojas, T. T \& Rojas, R. C. (2016). College of education graduate tracer study (gts): Boon or bane?. European Scientific Journal, 12(16), 63-78, https://dx.doi.or/10/19044/esj.2016.v12n16p63 
Analysis of Graduate Relevance to Program Learning Outcome Mechanical Engineering in State University of Surabaya

Yuhertiana, I. (2020). The impact of Indonesia new higher education accreditation criteria implementation. Journal of Critical Reviews, 7(3), 241-246. https://doi:10.31838/jcr.07.03.45

Yusoff, Y., Omar, M. Z, Zaharim, A., Mohammed, A., \& Muhammad, N. (2012) Formulation in evaluaing the technical skill of engineering graduates. Procedia-Social and Behavioral Sciences, 60(1), 493-499. https://doi.org/10.1016/j.sbspro.2012.09.413

Zaharim, A., Ahmad, I., Yusoff, Y., Omar, M. Z., \& Basri, H. (2012). Evaluating the soft skills performed by applicants of Malaysian engineers. Procedia-Social and Behavioral Sciences, 60(1), 522 - 528. https://doi.org/10.1016/j.sbspro.2012.09.417

\footnotetext{
*Heru Arizal, S.Pd., M.M., M.Pd. (Corresponding Author)

Departement of Mechanical Engineering, Faculty of Engineering

Universitas Negeri Surabaya

Jl. Lidah Wetan, Surabaya, East Java, 60213, Indonesia

Email: heruarizal@unesa.ac.id

Tri Hartutuk Ningsih, S.T., M.T.

Departement of Mechanical Engineering, Faculty of Engineering

Universitas Negeri Surabaya

Jl. Lidah Wetan, Surabaya, East Java, 60213, Indonesia

Email: triningsih@unesa.ac.id
}

\section{Ali Hasbi Ramadani, S.Pd., M.Pd.}

Departement of Mechanical Engineering, Faculty of Engineering

Universitas Negeri Surabaya

Jl. Lidah Wetan, Surabaya, East Java, 60213, Indonesia

Email: aliramadani@unesa.ac.id

Ika Nurjannah, S.Pd., M.T.

Departement of Mechanical Engineering, Faculty of Engineering

Universitas Negeri Surabaya

Jl. Lidah Wetan, Surabaya, East Java, 60213, Indonesia

Email: ikajannah@unesa.ac.id

Husni Mubarok, M.Sc.

Graduate Institute of Digital learning and Education, National Taiwan University of Science and Technology

No. 43號, Section 4, Keelung Rd, Da'an District, Taipei City, 106 Taiwan

Email: husnimubarok254@gmail.com 